\title{
Ready-to-eat meat products as a source of Listeria monocytogenes
}

\author{
Monika Kurpas, Kinga Wieczorek, Jacek Osek \\ Department of Hygiene of Food of Animal Origin \\ National Veterinary Research Institute, 24-100 Pulawy, Poland \\ josek@piwet.pulawy.pl
}

Received: September 20, 2017

Accepted: February 12, 2018

\begin{abstract}
In 2015 in the European Union member states listeriosis caused 270 deaths. Food is the route of transmission in $99 \%$ of all human infection cases. Several studies from different countries have shown that the presence of Listeria monocytogenes in food can be as high as $58.3 \%$. One of the most important ways to protect food from these microorganisms is to prevent the spread of the bacteria at processing plants at different stages of food production chain. The ability of $L$. monocytogenes to survive in extreme conditions and to form biofilms on various surfaces is a significant challenge for food safety. Removal of these bacteria from niches in processing plants is difficult and requires the use of sanitisers and precise equipment cleaning. The presence of L. monocytogenes in processing environment at slaughterhouses, deli meat factories or in retail may be a reason of cross-contamination. Proper hygienic systems applied by workers in food preparing places and knowledge about different routes of spreading of these bacteria may effectively decrease the risk of food contamination. Standardised legal regulations and control of meat product manufacture should be a fundamental way to protect food from L. monocytogenes contamination.
\end{abstract}

Keywords: ready-to-eat meat products, Listeria monocytogenes, contamination, food chain.

\section{Introduction}

Listeriosis is one of the most dangerous foodborne zoonoses with a high mortality rate reaching $20 \%-30 \%$ $(32,33,39)$. Although it is a relatively rare illness, with the notification rate of 0.46 cases per 100,000 persons in 2015 in the European Union (EU), most of the infections required hospitalisation $(97.4 \%)(9)$. At the same year 2,206 confirmed human listeriosis cases and 270 deaths were noted. In Poland in 2015, 70 people suffered from Listeria monocytogenes infection, with the notification rate of 0.18 (9). A significant increasing trend during 2011-2015 was observed in the EU member states, i.e. from 1,516 cases in 2011 to 2,242 in 2014 (9). In highrisk persons, e.g. the elderly, new-borns, or people with weakened immune system, listeriosis may manifest as meningitis, meningoencephalitis, septicaemia, and abortion $(29,31,32,36,39)$. The disease is caused by a ubiquitous microorganism - L. monocytogenes, a Gram-positive and non-spore-forming bacterium which can grow under anaerobic and aerobic conditions and survive even in extreme environmental conditions, a such as high concentration of salts, wide temperature range $\left(-0.4^{\circ} \mathrm{C}-45^{\circ} \mathrm{C}\right), \mathrm{pH}$ between 4 and 9.6 (40), and water activities $\geq 0.92 \quad$ (25). All these features make L. monocytogenes a foodborne pathogen extremely dangerous for humans, which can occur both in food and food production environment. These bacteria are often present in freezers, warehouses, and on surfaces in processing plants which have contact with food or raw products $(12,28)$. L. monocytogenes has been typed into four serotypes of which only three $(1 / 2 \mathrm{a}, 1 / 2 \mathrm{~b}, 4 \mathrm{~b})$ are involved in $95 \%$ of all human listeriosis cases (42).

As mentioned above, L. monocytogenes has a remarkable ability to survive under extreme environmental conditions, which has an impact on the spread of these bacteria in a broad range of foodstuff. Contaminated food is the most important route of transmission of these microorganisms to humans and it is responsible for about $99 \%$ listeriosis cases (25). Several studies have shown that different kinds of ready-to-eat (RTE) foods of animal origin were a vehicle for transmission of L. monocytogenes to consumers $(21,24)$. According to the latest EFSA report, in 2015 in the EU 
member states, the levels of contamination of RTE products were $3.5 \%$ of 2,847 of tested fish units and $4 \%$ of 2,366 of tested meat samples (9).

\section{RTE meat production chain}

The major steps in RTE meat production are farms, slaughterhouses, manufactures, shops, restaurants, and transport of products between these places. In each step of this food chain there are different possible sources of L. monocytogenes contamination. Reduction or elimination of the microorganisms from these places will be helpful in limiting the bacteria in the final food products. Most studies based on the "farm to fork" concept have shown that contamination of the final products usually occurs in processing plants or at the retail level and less often directly from food-producing animals $(19,26)$. Furthermore, human factor plays an important role, especially employees who do not comply with proper hygiene rules and may be vectors of L. monocytogenes along the food chain (Fig. 1).

It is important to distinguish potential routes of spreading of $L$. monocytogenes to know how to protect food and production environment from the bacterial contamination, as well as how different processes and environmental conditions influence the growth of the bacteria at different stages of the food chain. As it was mentioned, these microorganisms are able to survive under extremely different environmental conditions (25). Furthermore, they form biofilms on the surfaces of the processing equipment which may be a reservoir of these microorganisms for a long period, since L. monocytogenes is resistant to disinfectants, UV light, and desiccation $(8,33)$. It is difficult to remove bacterial biofilms, which makes them one of the most important hazards in food production process. There are few types of sanitisers which may be used in food environment and most of them are based on acid-anionic, halogen, hydrogen peroxide, quaternary ammonium, and chlorine $(21,34)$. Moreover, disinfection itself is not enough to eliminate $L$. monocytogenes from the production areas. It is also necessary to remove all food waste which may limit the contact of sanitiser agents with the bacterial biofilm by effective washing and rinsing of the surfaces before decontamination (33). Biofilm formation is often supported by accumulation of food residues in specific niches, like meat choppers or minced meat machines (8). It has been shown that L. monocytogenes is capable to form biofilm on stainless steel and glass or even polyvinyl chloride and polyethylene surfaces (4). The structure of the biofilm shows a great variety, from monolayer of cells to knitted chain network and honeycomb-like structure. Biofilm forming is influenced by L. monocytogenes factors, such as biofilm-associated protein (Bap), protein SecA2, and flagella, as well as environmental conditions, like temperature and adhesion properties of the surfaces (18). No correlation between L. monocyogenes molecular lineages or serovars and biofilm formation capacity has been observed $(4,7,8)$. Additionally, it has been shown that these bacteria are able to form biofilms with other microorganisms which may be present in the production environment, e.g. Pseudomonas or Staphylococcus. This may increase the strength of the biofilm structure and its resistance to the majority of cleaning and disinfection agents (18).

\section{Livestock as a source of $L$. monocytogenes in food}

Farms are the first stage of the RTE food production. At this level, the most important aspect is ensuring the proper state of the livestock health, which depends, among others, on proper veterinary management and quality of feed $(11,19)$. However, Hellström et al. (19) demonstrated that the presence of L. monocytogenes in pigs does not necessarily mean that pork meat products will be contaminated with these bacteria. From a total of 1,962 samples collected at farms (rectal swab and feed) and slaughterhouses (tonsils, pluck, carcass swabs), 119 (6\%) were positive for $L$. monocytogenes. The highest prevalence of these bacteria was detected in tonsils (24\%) and pluck sets $(5 \%)$ while the carcasses were contaminated only in $1 \%$. Genotyping investigation has shown that in the case of direct contact of carcass or pluck sets with tonsils there is a possibility to transfer L. monocytogenes to meat. It was also documented that proper methods during the slaughter can limit the prevalence of these bacteria in the final product. Some isolates of L. monocytogenes were detected in minced meat from the negative carcass, suggesting that contamination of meat occurred after processing as an effect of cross-contamination. In addition, these results suggest that L. monocytogenes was transferred to the products after slaughter of the animals as the meat from contaminated and not-contaminated carcasses was mixed $(19,26)$. In another study, prevalence of L. monocytogenes was much lower in carcasses $(2.4 \%)$ and in the intestines $(9.3 \%)$ than in the ground meat obtained from these animals $(50.2 \%)(26)$. This may also suggest that transmission of the bacteria is more likely post-slaughter, e.g. from the environment of slaughterhouse.

\section{Storage of meat and RTE food}

Storage time and conditions are important aspects in safety of RTE foods. During production of this kind of food it is important to use a raw meat free of L. monocytogenes. According to the EFSA guidelines, storage time should not exceed 15 days for red and 3 days for poultry meat at $7^{\circ} \mathrm{C}$ and $4^{\circ} \mathrm{C}$, respectively (10). However, contamination of meat products may also occur during and after processing (heat treatment, smoking, fermentation process) (23). Studies on kinetics of growth of L. monocytogenes in sliced packed salami showed that storage conditions had an impact on the survival of these bacteria. In the case of a low-dose inoculated samples stored at $5^{\circ} \mathrm{C}$ the time needed to reach the detection limit 
of L. monocytogenes was more than 16 days in air packing and more than 23 days in vacuum packing. For the same samples kept at $25^{\circ} \mathrm{C} \mathrm{L}$. monocytogenes has not been identified in air-packed or vacuum-packed conditions after 6 and 18 days, respectively. These results showed that higher temperature of storage and air packing decreased the level of L. monocytogenes faster than lower temperature and vacuum packing (14).

\section{L. monocytogenes in processing environment}

At RTE producing plants there are several dedicated zones, i.e. raw meat warehouse, preparing and packing areas, as well as final product stockrooms. In each of these locations there are possible sources of contaminations or cross-contamination, routes of spreading of L. monocytogenes, and potential problems with hygiene control.

Cold stores are the places where raw meat transported from slaughterhouses is kept. This is a critical area from which L. monocytogenes can be spread to other parts of the production facility. As it was mentioned, the bacteria are able to form biofilms on many surfaces, including floor drains (Fig. 1). The presence of L. monocytogenes in drains may result in the spread of the microorganism by water aerosol or during floor cleaning. The bacteria can also be transported with clothes and boots of workers, resulting in contamination of other zones of the plant $(8,34)$.

Contamination of RTE food may also be connected with slicing machines. Several surveys have shown that in food producing plants it is difficult to overcome contamination of the processing environment. One of the important preventing procedures is to properly separate places like cutting rooms and cooling zones or raw meat delivery corridors from other spaces, such as delivery areas of heat-treated products, packing rooms, or places with smoking and boiling equipment.

A proper hygienic system can prevent the crosscontamination with L. monocytogenes, which is a fundamental risk factor in RTE food facilities (33). A proper hygienic system can prevent the crosscontamination with L. monocytogenes, which is a fundamental risk factor in RTE food facilities (33).

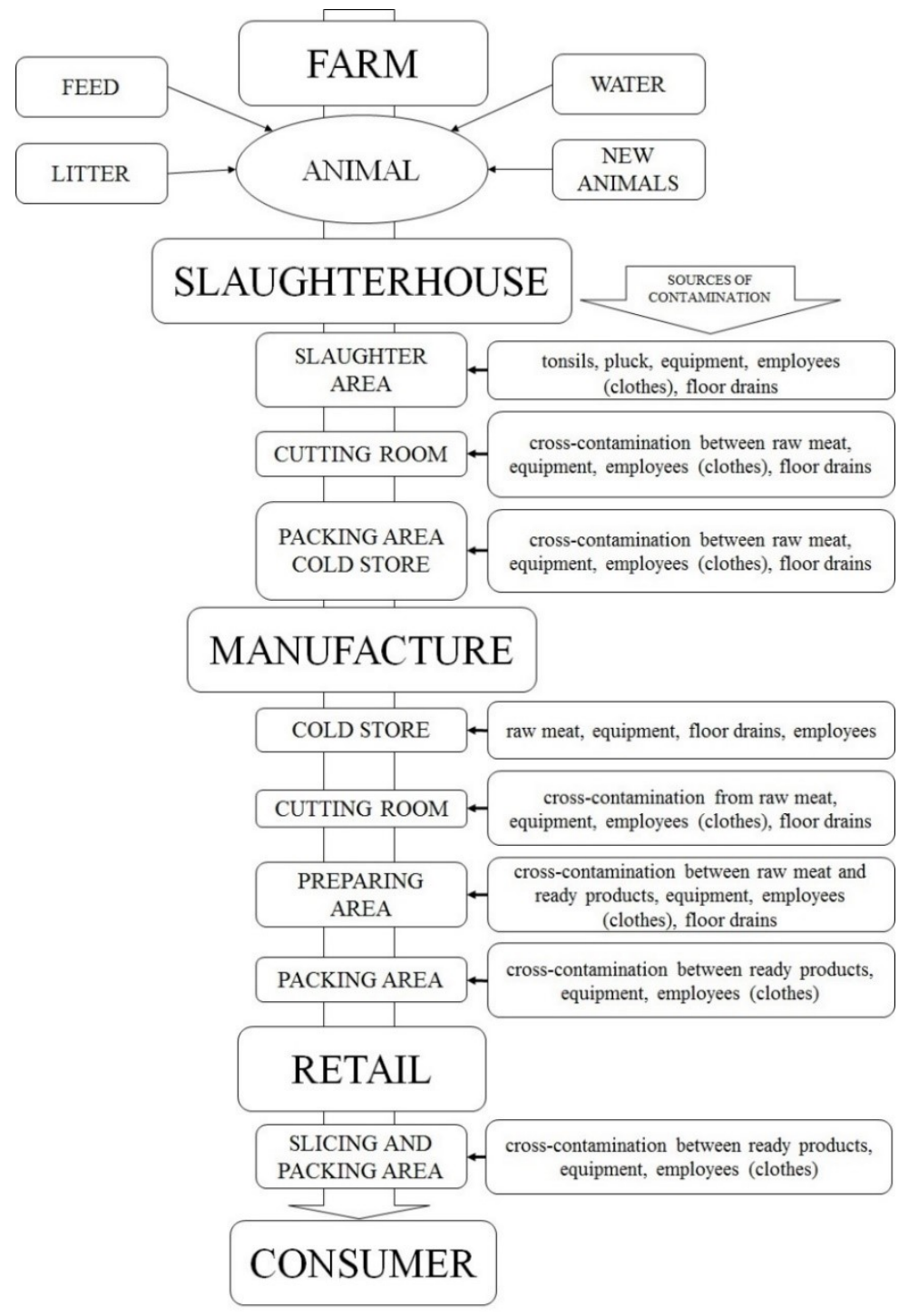

Fig. 1. Sources of L. monocytogenes at different stages of RTE meat production chain 
Therefore, to maintain a high hygiene standard and sterility in production areas, elaboration of effective methods of cleaning and disinfection of unavailable niches, where routine disinfections are ineffective, is needed $(16,20)$. It is necessary to select effective sanitisers (alkaline-, acid-, alcohol- and QAC-based products) and to determine their minimum inhibitory concentration (MIC) or minimum bactericidal concentration $(\mathrm{MBC})$ to choose the best solution for a given production facility (34).

\section{L. monocytogenes in retail}

Many studies demonstrated that deli products sliced in retail shops often have a higher level of bacterial contamination than products prepared in deli meat factories (3). As tested in the USA, approximately $83 \%$ of listeriosis cases caused by deli meats were associated with products sliced at retail (35). Preparation of such RTE food in shops increases the risk of cross-contamination of products from different manufactures (21). Chaitiemwong et al. (3) showed that risk of higher concentration of bacteria increased when deli products were sliced separately for individual customers. Furthermore, it was documented that the last slice often had a higher number of $L$. monocytogenes than the previous ones (3). In smaller shops and local deli meat factories inadequate quality or number of equipment used for preparation of RTE foods may also cause a higher contamination risk of the final sliced products. Moreover, lack of the appropriate sanitisers and inaccurate washing of polyethylene and wooden cutting boards may result in the persistence of L. monocytogenes and cross-contamination of other food products. Guat Goh et al. (15) revealed that the number of L. monocytogenes on chicken meat in comparison with the number of bacteria found on the cutting board depended, among others, on the material from which the cutting board was made. In the case of the transfer of bacteria from wooden board to chicken meat (30 min after cutting the contaminated raw meat on the same cutting board), the probability of cross-contamination was $73.5 \%$, whereas in the case of a plastic cutting board it amounted to $90.2 \%(15)$.

\section{L. monocytogenes in RTE food - legal regulations}

To establish legal regulations concerning the prevalence of L. monocytogenes in food, the Food and Agriculture Organization of the United Nations (FAO) and the World Health Organization (WHO) established international standards called Codex Alimentarius. One of the Codex documents (CAC/GL 61-2007) refers to the standards in food hygiene to control L. monocytogenes in meat products (17). Another important international legislative document is ISO 22000:2005 which is applied in Food Safety Management Systems (FSMS) based on
Good Hygiene Practices and Production (GHMP), as well as in Hazard Analysis and Critical Control Points (HACCP) (19). However, despite well-regulated global standardised rules of hygiene in food production chain, there are still many countries where problems with food contamination with L. monocytogenes are difficult to solve. This situation is often due to the lack of sufficient knowledge about the risk of infection, both on the part of consumers and food manufacturers.

In the European Union the criteria on the presence of L. monocytogenes in RTE food are the same as in the Codex and they are specified in Commission Regulation (EC) No. 2073/2005 as later amended. It has been established that food business operators are responsible for application of the relevant criteria for different kinds of food. The number of L. monocytogenes must not exceed the limit of $100 \mathrm{cfu} / \mathrm{g}$ during the shelf life of food which is unable to support the growth of these bacteria, or L. monocytogenes is absent in $25 \mathrm{~g}$ in RTE food which is able to support the growth of these microorganisms (5). The infective dose in most of listeriosis cases is $>10^{4} \mathrm{cfu} / \mathrm{g}$ and for immunocompromised patients it could be even $100 \mathrm{cfu} / \mathrm{g}$ (39). According to the recent EFSA report concerning the food contamination with L. monocytogenes, for RTE products on the market less than $0.3 \%$ of single samples and $0 \%-1.4 \%$ of batched samples were found to comply with the criterion of $\leq 100$ $\mathrm{cfu} / \mathrm{g}$ of Regulation (EC) No 2073/2005. However, higher levels of non-compliance (primarily presence in $25 \mathrm{~g}$ ) have been reported in similar samples of the comparable processing stage, from $0 \%$ to $3.5 \%$ in single samples and from $0 \%$ to $6.1 \%$ in batch samples, respectively. For the RTE products of meat origin, contamination with L. monocytogenes was $1.62 \%$ for batch samples and $2.07 \%$ for single samples, respectively (9).

There are many publications describing the presence of L. monocytogenes in RTE food products (Table 1). It can be concluded that food contamination with these microorganisms is still a problem, both in developed and developing countries.

\section{Conclusions}

Listeriosis is a very dangerous zoonosis, which, despite its low incidence, remains a major public health concern due to high mortality rate. Several studies have shown that RTE food is one of the most important vehicles responsible for human infections. To ensure the safety of such meat products one has to pay attention to many factors at different stages of the production chain. It is important to standardise food law and procedures for hygiene and sanitation in processing plants in different countries. Strains of L. monocytogenes display differences in virulence and epidemic potential, and a limited number of serotypes have been responsible for human foodborne infections. Molecular typing of these bacteria plays an important role in epidemiology and foodborne outbreak investigation. 
Table 1. Contamination of RTE products in different countries

\begin{tabular}{|c|c|c|c|c|}
\hline Country & Food product & Number of samples tested & Percentage of positive samples & Reference \\
\hline \multicolumn{5}{|l|}{ Europe } \\
\hline \multirow[t]{2}{*}{ Serbia } & Cooked meat products & 311 & $0.96 \%$ & 2 \\
\hline & Cured meat products & 111 & $4.5 \%$ & \\
\hline \multirow[t]{3}{*}{ Spain } & Cooked meat products & 35 & $5.71 \%$ & 13 \\
\hline & Raw-cured products & 57 & $5.26 \%$ & \\
\hline & Dry-cured products & 37 & $2.7 \%$ & \\
\hline Sweden & Heat treated meat products & 507 & $1.2 \%$ & 28 \\
\hline Italy & Salami & 112 & $20.5 \%$ & 6 \\
\hline Portugal & Dry-cured ham & 44 & $2.3 \%$ & 31 \\
\hline \multirow[t]{3}{*}{ United Kingdom } & Cooked meat & 1,321 & $2.2 \%$ & 30 \\
\hline & Pâté & 411 & $0.24 \%$ & \\
\hline & Fermented meats & 316 & $1.9 \%$ & \\
\hline \multirow[t]{2}{*}{ Austria } & Cooked sausage-Pâté & 112 & $4.5 \%$ & 41 \\
\hline & Fermented sausages & 65 & $1.5 \%$ & \\
\hline Poland & Cooked sausage & 84 & $2.38 \%$ & 27 \\
\hline \multirow[t]{3}{*}{ Slovakia } & L’udová salami & 11 & $54 \%$ & 24 \\
\hline & Ham sausage & 8 & $37.5 \%$ & \\
\hline & Ipel’ská sausage & 12 & $58.3 \%$ & \\
\hline Turkey & Cooked red meat & 31 & $6.4 \%$ & 43 \\
\hline \multicolumn{5}{|l|}{ Asia } \\
\hline \multirow[t]{2}{*}{ Japan } & RTE raw meats & 96 & $3.1 \%$ & 38 \\
\hline & Heat treated meat products & 1,091 & $0.8 \%$ & \\
\hline Malaysia & Sausages & 30 & $13.3 \%$ & 29 \\
\hline \multirow[t]{2}{*}{ China } & Cooked meat & 62 & $6.5 \%$ & 37 \\
\hline & Cooked meat & 55 & $7.2 \%$ & 42 \\
\hline \multicolumn{5}{|l|}{ South America } \\
\hline \multirow[t]{2}{*}{ Chile } & Cooked sausage & 41 & $13 \%$ & 32 \\
\hline & Pâté & 62 & $55 \%$ & \\
\hline \multirow[t]{3}{*}{ Colombia } & Sausage & 169 & $7.69 \%$ & 11 \\
\hline & Ham & 10 & $6.13 \%$ & \\
\hline & "Choriso" & 67 & $4.03 \%$ & \\
\hline Trinidad and & Deli meats & 70 & $1.4 \%$ & 22 \\
\hline \multicolumn{5}{|l|}{ Tobago } \\
\hline Brazil & Pork sausage & 138 & $39.8 \%$ & 36 \\
\hline \multicolumn{5}{|l|}{ North America } \\
\hline Canada & Fermented sausage & 100 & $4 \%$ & 1 \\
\hline
\end{tabular}


Conflict of Interests Statement: The authors declare that there is no conflict of interests regarding the publication of this article.

Financial Disclosure Statement: This work was funded by the Leading National Research Centre (KNOW), Scientific Consortium "Healthy Animal - Safe Food", Ministry of Science and Higher Education resolution No. 05-1/KNOW/2015.

\section{Animal Rights Statement: None required}

\section{References}

1. Bohaychuk V.M., Gensler G.E, King R.K., Manninen K.I., Sorensen O., Wu J.T., Stiles M.E., McMullen L.M.: Occurrence of pathogens in raw and ready-to-eat meat and poultry products collected from the retail marketplace in Edmonton, Alberta, Canada. J Food Protect 2006, 69, 2176-2182.

2. Borović B.B., Baltić T., Lakićević B., Janković V., Mitrović R. Jovanović J., Lilić S.: Prevalence of Listeria monocytogenes in ready-to-eat food of animal origin. Meat Technol 2014, 55, $117-122$.

3. Chaitiemwong N., Hazeleger W.C., Beumer R.R., Zwietering M.H.: Quantification of transfer of Listeria monocytogenes between cooked ham and slicing machine surface. Food Control 2014, 44, 177-184

4. Colagiorgi A., Di Ciccio P., Zanardi E., Ghidini S., Ianeri A.: A look inside the Listeria monocytogenes biofilms extracellular matrix. Microorganisms 2016, 4, 1-12.

5. Commission Regulation (EC) No 2073/2005 of 15 November 2005 on microbiological criteria for foodstuffs. OJ L 2005, 338.

6. Di Pinto A., Novello L., Montemurro F., Bonerba E., Tantillo G.: Occurrence of Listeria monocytogenes in ready to eat foods from supermarkets in southern Italy. New Microbiol 2010, 33, 249-252.

7. Doijad S.P., Barbuddhe S.B., Garg S., Poharkar K.V., Kalorey D.R., Kurkure N.V., Rawool D.B., Chakraborty T.: Biofilmforming abilities of Listeria monocytogenes serotypes isolated from different sources. PLos ONE 2015, 10, 1-14.

8. Dzieciol M., Schornsteiner E., Muhterem-Uyar M., Stessl B., Wagner M., Schmitz-Esser S.: Bacterial diversity of floor drain biofilms and drain waters in Listeria monocytogenes contaminated food processing plants. Int J Food Microbiol 2016, 223, 33-40.

9. European Food Safety Authority (EFSA), European Centre for Disease Prevention and Control (ECDC): The European Union summary report on trends and sources of zoonoses, zoonotic agents, and food-borne outbreaks in 2015. EFSA J 2016, 14.

10. European Food Safety Authority (EFSA): Scientific opinion on the public health risks related to the maintenance of the cold chain during storage and transport of meat. Part 2 (minced meat from all species). EFSA J 2014, 12

11. Gamboa-Marín A., Buitrago S.M., Pérez-Pérez K., Mercado M.R., Poutou-Piñales R., Carrascal-Camacho A.: Prevalence of Listeria monocytogenes in pork-meat and other processed products from the Colombian swine industry. Rev MVZ Cordoba 2012, 17, 2827-2833.

12. Gómez D., Azón E., Marco N., Carramiñana J.J., Rota C., Ariño A., Yangüela J.: Antimicrobial resistance of Listeria monocytogenes and Listeria innocua from meat products and meat-processing environment. Food Microbiol 2014, 42, 61-65.

13. Gómez D., Pilar Iguácel L., Rota C., Carramiñana J.J., Ariño A., Yangüela J.: Occurrence of Listeria monocytogenes in ready-toeat meat products and meat processing plants in Spain. Foods 2015, 4, 271-282.

14. Gounadaki A.S., Skandamis P.N., Drosinos E.H., Nychas G.J.: Effect of packaging and storage temperature on the survival of
Listeria monocytogenes inoculated postprocessing on sliced salami. J Food Protect 2007, 70, 2313-2320.

15. Guat Goh S., Leili A.-H., Hao Kuach C., Ying Loo Y., Ling Lye Y., San Chang W., Soopna P., Shahril Najwa M., Yew Huat Tang J., YaYa R., Nishibuchi M., Nakaguchi Y., Son R.: Transmission of Listeria monocytogenes from raw chicken meat to cooked chicken meat through cutting boards. Food Control 2014, 37 51-55.

16. Gudbjörnsdóttir B., Suihko M.-L., Gustavsson P., Thorkelsson G., Salo S., Sjöberg A.-M., Niclasen O., Bredholt S.: The incidence of Listeria monocytogenes in meat, poultry and seafood plants in the Nordic countries. Food Microbiol 2004, 21, 217-222.

17. Guidelines on the application of general principles of food hygiene to the control of Listeria monocytogenes in foods CAC/GL 61-2007.

18. Guilbaud M., Piveteau P., Desvaux M., Brisse S., Braindet R.: Exploring the diversity of Listeria monocytogenes biofilm architecture by high-throughput confocal laser scanning microscopy and the predominance of the honeycomb-like morphotype. Appl Environ Microbiol 2015, 81, 1813-1819.

19. Hellström S., Laukkanen R., Siekkinen K.-M., Jukka R., Maijala R., Korkeala H.: Listeria monocytogenes contamination in pork can originate from farms. J Food Protect 2010, 73, 641-648.

20. Henriques A.R., Gama L.T., Fraqueza M.J.: Tracking Listeria monocytogenes contamination and virulence associated characteristic in the ready-to-eat meat-based food products industry according to hygiene level. Int J Food Microbiol 2017, 242, 101-106.

21. Hoelzer K., Pouillot R., Gallagher D., Silverman M.B., Kause J., Dennis S.: Estimation of L. monocytogenes transfer coefficients and efficacy of bacterial removal through cleaning and sanitation. Int J Food Microbiol 2012, 157, 267-277.

22. Hosein A., Muñoz K., Sawh K., Adesiyun A.: Microbial load and the prevalence of Escherichia coli, Salmonella spp., and Listeria spp. in ready-to-eat products in Trinidad. Open Food Sci J 2008, 2, 23-28.

23. Ingham S.C., Buege D.R., Dropp B.K., Losinski J.A.: Survival of Listeria monocytogenes during storage of ready-to-eat meat products processed by drying, fermentation, and/or smoking. J Food Protect 2004, 67, 2698-2702.

24. Kačániová M., Kluz M., Petrová J., Mellen M., Kunová S.: Incidence of Listeria monocytogenes in meat product samples by real time PCR. Mod Chem Appl 2015, 3, 1-5.

25. Kanarat S., Jitnupong W., Sukhapesna J.: Prevalence of Listeria monocytogenes in chicken production chain in Thailand. Thai J Vet Med 2011, 41, 155-161.

26. Kanuganti S.R., Wesley I.V., Reddy P.G., McKean J., Hurd H.S. Detection Listeria monocytogenes in pigs and pork. J Food Protect 2002, 65, 1470-1474.

27. Kwiatek K.: Occurrence of Listeria monocytogenes in selected food of animal origin. Bull Vet Inst Pulawy 2004, 48, 269-272.

28. Lambertz S.T., Nilsson C., Brådenmark A., Sylvén S., Johansson A., Jansson L.-M., Lindblad M.: Prevalence and level of Listeria monocytogenes in ready-to-eat foods in Sweden 2010. Int J Food Microbiol 2012, 160, 24-31.

29. Marian M.N., Sharifah Aminah S.M., Zuraini M.I., Son R., Maimunah M., Lee H.Y., Wong W.C., Elexson N.: MPN-PCR detection and antimicrobial resistance of Listeria monocytogenes isolated from raw and ready-to-eat foods in Malaysia. Food Control 2012, 28, 309-314

30. Meldrum R.J., Ellis P.W., Mannion P.T., Halstead D., Garsiede J.: Prevalence of Listeria monocytogenes in ready-to-eat foods sampled from the point of sale in Wales, United Kingdom. J Food Protect 2010, 73, 1515-1518

31. Mena C., Almeida G., Carneiro L., Teixiera P., Hogg T., Gibbs P.A.: Incidence of Listeria monocytogenes in different food products commercialized in Portugal. Food Microbiol 2004, 21, 213-216.

32. Montero D., Bodero M., Riveros G., Lapierre L., Gaggero A., Vidal R.M., Vidal M.: Molecular epidemiology and genetic diversity of Listeria monocytogenes isolates from a wide variety 
of ready-to-eat foods and their relationship to clinical strains from listeriosis outbreaks in Chile. Front Microbiol 2015, 6, 1-8.

33. Muhterem-Uyar M., Dalmasso M., Bolocan A.S., Hernandez M., Kapetanakou A.E., Kuchta T., Manios S.G., Melero B., Minarovicova J., Nicolau A.I., Rovira J., Skandamis P.N., Jordan K., Rodríguez-Lazaroa F., Stessl B., Wagner M.: Environmental sampling for Listeria monocytogenes control in food processing facilities reveals three contamination scenarios. Food Control 2015, 51, 94-107.

34. Pan Y., Breidt F. Jr., Kathariou S.: Resistance of Listeria monocytogenes biofilms to sanitizing agents in simulated food processing environment. Appl Environ Microbiol 2006, 72, 7711-7717.

35. Quesenberry H.H., Gallagher D., Endrikat S., LaBarre D., Ebel E., Schroeder C., Kause J.: Comparative risk assessment for Listeria monocytogenes in ready-to-eat meat and poultry deli meats report. FSIS, USDA 2010.

36. Ristori C.A., Gravato Rowlands R.E., Geraldes Martins C., Barbosa M.L., Yoshida J.T.U., Bernadette D.G. de Melo Franco B.D.G.: Prevalence and populations of Listeria monocytogenes in meat products retailed in Sao Paulo, Brazil. Foodborne Pathog Dis 2014, 11, 969-973.

37. Shi W., Qingping W., Zhang Jumei Z., Moutong C., Zean Y.: Prevalence, antibiotic resistance and genetic diversity of Listeria monocytogenes isolated from retail ready-to-eat foods in China. Food Control 2015, 47, 340-347.

38. Shimojima Y., Ida M., Nakama A., Nishino Y., Fukui R., Kuroda S., Hirai A., Kai A., Sadamasu K.: Prevalence and contamination levels of Listeria monocytogenes in ready-to-eat foods in Tokyo, Japan. J Vet Med Sci 2016, 78, 1183-1187.

39. Swaminathan B., Gerner-Smidt P.: The epidemiology of human listeriosis. Microbes Infect 2007, 9, 1236-1243.

40. Valimaa A.L., Tilsala-Timisjearvi A., Viirtanen E.: Rapid detection and identification methods for Listeria monocytogenes in the food chain. A review. Food Control 2015, 55, 103-114.

41. Wagner M., Auer B., Trittremmel C., Hein I., Shoder D.: Survey on the Listeria contamination of ready-to-eat food products and household environments in Vienna, Austria. Zoonoses Public Hlth 2006, 54, 16-22.

42. Wang W., Zhou X., Suo Y., Deng X., Cheng M., Shi C., Shi X.: Prevalence, serotype diversity, biofilm-forming ability and eradication of Listeria monocytogenes isolated from diverse foods in Shanghai, China. Food Control 2017, 73, 1068-1073.

43. Yucel N., Citak S., Onder M.: Prevalence and antibiotic resistance of Listeria species in meat products in Ankara, Turkey. Food Microbiol 2005, 22, 241-245. 